\title{
The Main Agency Problems and Their Consequences
}

\author{
Magdalena Jerzemowska*
}

According to perceived wisdom the main aim of a company is to maximize its stock market value. Managers of the company are responsible for achieving that aim, i.e. for maximizing shareholders' wealth. The performance that a company achieves reveals how successful the management is in adapting to changing circumstances. The ability to quickly and properly react to changes in the business environment characterizes the quality of the company's management.

Campbell and Underdown (1991, p. 2-3) argue that the success of any business enterprise is determined by the interaction of two major sets of factors - external factors and internal factors. The latter are beyond the control of business managers and include such environmental conditions as shifting preferences, the behaviour of consumers, adverse movements in commodity prices, changes in government policy and cyclical market forces. The internal factors emanate from inside the firm and encapsulate the ability of management to develop and implement planning strategies that fit the business to the environment. The probability of changes in environmental factors and the effects of such changes on future business performance should be taken into account if an enterprise is to survive and prosper.

The firm's performance, represented by gross profit (II), depends on the manager's effort (e) and also a chance variable (a), determines after e is chosen (Hart, 1995, p. 105):

$$
\mathrm{II}=\mathrm{g}(\mathrm{e}, \mathrm{a})
$$

According to the theory of the relationship between principals (owners) and agents (managers) - principal-agent theory - owners hires managers to run the firm on their behalf.

The aim of company, which was earlier noted to be maximization of the market value of the company, often is not compatible with the interests of managers, as they prefer to maximize their own personal interests, if possible, even at the expense of owners. This discrepancy of interests leads to agency conflicts, which are especially severe in public companies (Jensen - Meckling, 1976). The separation of ownership and control causes serious conflicts of interests, among which the conflict between shareholders and managers, and shareholders (represented by managers) and creditors are the most important.

It must be remembered - that present - day companies do not have owners in the traditional sense. Shareholders are typically dispersed and are unable to manage the entities that they own (Jerzemowska, 1999). They have to hire agents (managers) to manage the firm on their behalf. In practice, shareholders act as investors not owners. The difference is subtle, but important. Owners focus on the business performance of the firm and investors focus on the risk and return of their stock portfolios. Therefore, investors tend to be inactive shareholders in many firms (Kim - Nosfinger, 2004, p. 4). This conflict between shareholders and managers has resulted in the formulation of contracts to mediate the agency relationship.

\footnotetext{
Prof. Dr. hab. Magdalena Jerzemowska - Professor; Department of Economic Analysis, Gdansk University, 81-824 Sopot, Armii Krajowej 101, Poland; <analyza@wzr.pl>.
} 
According to the stakeholder view the existence of a firm is possible because of a set of compromises, called a "nexus of contracts", in which the interests of particular groups are agreed. To limit agency conflicts some special costs, called agency costs, have to be incurred. They may be defined in several ways. Ross, Westerfield and Jaffe (2005) define them as additional costs resulting from the existence of conflict situations among stakeholders, which are incurred by the owners of a firm when ownership and control are separated (Moyer - McGuigan - Kretlow, 1992, p. 517). They argue that agency costs are the costs which arise from the conflicts of interest among shareholders, bondholders, and managers. They may be defined as the costs of resolving these conflicts. They include the costs of providing managers with an incentive to maximize shareholder wealth and of then monitoring their behaviour, and the cost of protecting bondholders from shareholders. Agency costs are always borne by stockholders (Ross - Westerfield - Jaffe, 2005, p. 891).

According to Jensen and Meckling (1976, p. 308) agency costs are the sum of:

1. the monitoring expenditures of the principal;

2. the bonding expenditures by the agent;

3. the residual loss.

Residual loss is the reduction in the value of the firm that arises when the entrepreneur dilutes his ownership. In the opinion of Williamson (1988, p. 322) this is the key cost, since the other two are incurred only to the extent that they yield cost-effective reductions in the residual loss. The shift out of profits into managerial discretion, induced by a dilution of ownership, is responsible for this loss. Monitoring expenditures and bonding expenditures can help to restore performance toward the pre-dilution levels. The irreducible agency cost is the minimum of the sum of these three factors.

A solution to the problem of agency costs may be found in the use of managerial incentives and the effectiveness of managerial monitoring. The incentive solution is to tie the wealth of the executives to the wealth of shareholders. In this way the interests of these two groups are aligned. Executives may be given stock or stock options, or both, as a significant component of their compensation. The second solution is to set up mechanisms for monitoring the behaviour of managers (Kim - Nofsinger, p. 4-5).

Agency costs are a kind of transaction costs connected with way in which a firm is organized. They are real costs which depend on legal regulations and the willingness of people to sign contracts, among others. They are always present in all companies and at every level of management and, as pointed out earlier, are always borne by current shareholders (Ross - Westerfield - Jaffe, 2005, p. 891). The purpose of incurring them is to assure that managers will act in the best interests of the capital suppliers. Creditors incur them by asking for higher interest, and potential shareholders by paying lower prices per share. Thus, the higher the expected costs of governance, the higher the interest rate and the lower the market value of a firm, other factors being the same.

Damodaran (1997, p. 456) states that agency costs may show up in two ways as real costs. First, if bondholders believe there is a significant chance that shareholder actions might make them worse off, they can build these expectations into bond prices by demanding much higher interest rates on debt. Second, if bondholders can protect themselves against such actions by writing in restrictive covenants, two costs arise: the direct costs of monitoring the covenants, which increases as the covenants become more detailed and restrictive; and the indirect costs of lost flexibility, because the firm is not able to invest in cer- 
tain projects, use certain types of financing, or change its payout. This latter his cost will also increase as the covenants become more restrictive.

According to Samuels, Wilkes and Brayshaw (1995, p. 662) there is disagreement as to whether the agency costs associated with debt are greater or less than those associated with equity. Jensen and Meckling (1976) are of the view that agency costs are additional expenses, either direct or indirect, which are incurred in ensuring that agents act in the best interests of the principals and the suppliers of debt. The reason for the existence of these costs is the possibility that managers are able to undertake policies detrimental to the providers of debt if constraints of some sort were not placed upon them.

\section{Conflicts of interest between managers and shareholders}

It should be stressed that the most severe conflict of interests exists between shareholders (principals) and managers (agents) (masulis, 1988, p. 47). This situation exists despite the right of shareholders to manage the company by participating in, and voting during, the Annual General Meeting. They have the right to appoint and dismiss managers, accept financial statements and appoint auditors. They may also sell the shares that they own and put their company at risk of being taken over, or even being declared bankrupt.

According to Masulis (1988, p. 48) these conflicts arise for the following four reasons:

1. managers prefer greater levels of consumption and less intensive work, as these factors do not decrease their remuneration and the value of the company's shares that they own;

2. managers prefer less risky investments and lower financial leverage, because in this way they may decrease the danger of bankruptcy, and avoid losses on their managerial capital and portfolios;

3. managers prefer short-term investment horizon;

4. managers avoid problems stemming from reductions in employment levels, which increase with the changes in control of a company.

Murphy (1985) argues that mangers tend to increase the size of companies even if it harms the interests of shareholders, as quite often their remuneration and prestige are positively correlated with company size. These inclinations cause conflicts of interest between managers, who tend to value expansion, and shareholders, who are orientated towards the maximization of the value of their shares. If sufficient internal funds are available, managers may be motivated to undertake investments of dubious profitability that would be rejected by the capital market.

Several mechanisms may serve to limit the conflicts of interest between managers and shareholders by aligning the interests of both groups. For example, share options link managerial remuneration to firms' performance. Jensen (1986) expresses the view that limiting managers' freedom of action has a crucial role to play in reducing the agency costs of equity, and recommends the reduction of free cash flow as a solution. ${ }^{1}$ According to this hypothesis, dividend payouts, share repurchases and incurring extra debt serve to reduce the amount of money under mangers' control. These actions decrease free cash flow and reduce the likelihood of unprofitable and expansion orientated investments being undertaken

1 Free cash flow is the excess of that required to fund all projects that have positive net present values when discounted at the relevant cost of capital. (Jensen, 1986). 
(Jensen, 1986). The payment of dividends is less important here, as it is always possible to stop dividend payments. It must also be remembered that the issue of new shares dilutes shareholders (and managers) holdings, and that if insufficient control is obtained it will not protect against the wasting of financial resources by the managers of a company.

Compensation in the form of shares is well suited to control excessive consumption by managers, and also the time-horizon of investments, which influence price of shares. Manager's options, and voting rights stemming from ownership of shares, are important means to control the agency problems, given the risk aversion of managers. As managers increase their equity participation they are likely to become more effective. They are likely to become more prudent and avoid undertaking risky investments as they may threaten their own interests (Shapiro, 1999, p. 470).

\section{Conflicts between creditors and mangers (shareholders)}

Conflicts between creditors and managers (shareholders) are the second, most severe, and most important conflict of interest that exist in companies. Managers using debt agree to incur real agency costs and limit their freedom in making decisions. Conflicts between shareholders and debtholders manifest themselves in the choice of projects to take (investment decisions) and in determining how to finance these projects and how much to pay out as dividends (Damodaran, 1997, p. 454).

Increases in debt are directly related to increases in risk, especially bankruptcy risk. Debt not only reduces free cash flow, but also increases the probability of bankruptcy. It should be noted that, from a legal point of view, bankruptcy is the process of scheduling the debt payments due to creditors when a company is in distress. From an economic point of view it is a mechanism for allocating resources (Peterson, 1994, p. 615). According to Masulis (1988, p. 50) managers cannot afford to waste the limited resources under their discretion in situations where the burden of debt is heavy. Therefore, Jensen (1986) argues that increases in debt should increase the market value of a company, as long as bankruptcy costs are kept at a low level (Damodaran, 1997, p. 455). Increasing financial leverage is therefore one of the possible ways of reducing the agency costs associated with equity.

Managers that decide to increase debt limit their freedom to dispose of free cash flow and are subject to capital market discipline. Shareholders may use the increase in debt as a means of controlling managers. Managers have a very strong incentive to generate the financial resources needed to service the debt. Financial leverage is, therefore, used to restructure ownership claims and at the same time to change the aims and aspirations of managers to fully maximise the value of the company's assets at their disposal. (Jensen, 1986)

The ability to make optimal risky investments differs between firms, and depends on Prowse, 1990):

- differences in the use of assets;

- the costs of monitoring assets by creditors;

- the benefits that shareholders derive from the use of assets. 
Managers, who are obliged to maximize the interests of shareholders, may in fact make decisions that are aligned with the interests of bondholders. The latter may take special steps to protect themselves by including protective covenants in bond agreements. These covenants limit the company's flexibility, for example to issue further debt, and thus maintain risk at a certain level (Samuels - Wilkes - Brayshaw, 1995, p. 662). Another example of a bond covenant is a protective put. This allows a bondholder to return the bonds to the issuer before maturity and receive the face value (Damodaran, 1997, p. 455; Ross - Westerfield - Jaffe, 2005, p. 441). Covenants often require financial conditions to be maintained (working capital requirements, interest cover, a minimal level of net worth) and may impose restrictions in the event of asset disposals (Ross - Westerfield - Jaffe, 2005, p. 442). Covenants are the cheapest way of limiting conflicts of interest between shareholders and bondholders, and must be taken seriously since a broken covenant can lead to default.

Protective covenants can be classified into two types: negative covenants and positive covenants. Negative covenants limit or prohibit actions that the company may take, for example:

- Limitations are placed on the amount of dividends a company may pay.

- The firm may not pledge any of its assets to other lenders.

- The firm may not merge with another firm.

- The firm may not sell or lease its major assets without approval by the lender.

- The firm may not issue additional long-term debt.

A positive covenant specifies an action that the company agrees to take or a condition the company must abide by. The examples of such covenants are:

- The company agrees to maintain its working capital at a minimum level.

- The company must furnish periodic financial statements to the lender.

Restrictive covenants may vary with respect to restrictiveness. Shareholders gain from losses incurred by bondholders, even when the risk associated with the firm's assets increases, because it decreases the market value of the firm's assets. Managers may reduce the value of current bonds by issuing new debt, which increases the riskiness of the firm. The increase in risk shifts the benefits from bondholders to shareholders. It compensates shareholders for the decrease in the market value of the firm. There are three kinds of "selfish" strategies that shareholders use to "hurt" bondholders and help themselves when there is a probability of bankruptcy or financial distress. They are costly because they lower the market value of the whole firm. The strategies are:

1. Incentive to take large risks.

2. Incentive towards underinvestment.

3. "Milking the property". 
It must be remembered that costs of selfish strategies are paid by shareholders. Rational bondholders are aware that, when financial distress is imminent, they cannot expect help from shareholders, who are likely to choose investment strategies that reduce the value of the bonds. Accordingly, bondholders protect themselves by raising the required interest rate on the bonds. Because shareholders must pay these high rates, they ultimately bear the costs of selfish strategies.

Protective covenants should reduce the costs of bankruptcy, ultimately increasing the value of the firm.

Securitization of debt is one means of protecting bondholders' interests that may be incorporated in loan agreements. It is achieved by granting creditors property rights to certain part of a firm's assets till the loan is repayed. The collateral on fixed assets may significantly reduce agency costs. Leasing contracts are one way of achieving this outcome. They increase the probability that investments with positive net present value will be undertaken, because managers will have to increase shareholders' returns by undertaking new investments, not by exploiting creditors (Emery - Finnerty, 1991, p. 439). Debt increases helps to make managers' actions more rational and to make value-maximising decisions (Green, 1993).

Another source of conflict between shareholders and managers are decisions concerning dividend payouts and share repurchases. Such actions negatively affect the market value of bonds, but have a positive impact on a company's shares. A firm that has financial strength should use them in accordance with creditors' preferences for the repayment of debt, in this way reducing financial risk and the costs of bankruptcy, but not shifting them to shareholders.

Companies operate with the privilege of limited liability for the debts of their shareholders, and also to some extent of their managers. In some E.U. member countries (the U.K. France, and Belgium) managers are responsible for wrongful trading. The Winter's Report suggests that the liability of managers should be better defined and recommends that managers should be personally responsible for losses incurred by creditors (and also by shareholders). It is recommended that managers be punished for continuing to trade in a situation where insolvency is expected. This suggestion is compatible with the British Insolvency Act of 1986, which states that courts may order managers to pay an amount of money that they deem to be adequate. An amended to the 2002 Polish bankruptcy law also includes such a sanction.

Section III.13 of the Winter's Report recommends the implementation of the principle of sanctions against wrongful trading in the E.U. The introduction of such a principle will serve to increase the trust of creditors towards managers and ensure the protection of their interests in all member countries. This principle will not cause any problems for firms in a healthy financial condition.

Directors may avoid personal responsibility, if they can show that they took all of the necessary steps to minimize potential losses to the company's creditors. They must prove that they took the actions expected from a person with an adequate level of knowledge, skills and professional experience, and also demonstrate that they possess the required level of skills and experience. ${ }^{2}$

Finally, a U.K. director who has participated in wrongful trading may be disqualified under the terms of section 10 of the Company Directors Disqualification Act 1986. This

237 Insolvency Law and Practice, Report of the Insolvency Law Review Committee, Cmnd.8558, 1982 S.214 (4). 
means that a director is prevented from continuing to act as a director (whether directly or indirectly) or from in any way being concerned with the promotion, formation or management of a company.

There are three main categories of cases, in which the court may make a disqualification order (Campbell, 1991, p. 6-7):

1. where there has been general misconduct in the affairs of the company or misconduct or fraud in relation to the promotion or management of the company;

2. disqualification for unfitness;

3. disqualification after a liability has been imposed for wrongful trading.

It should be noted that the introduction in the U. K. of the Insolvency Act and the Company Directors Disqualification Act, and the sanctions stemming from them, has resulted in managers of distressed companies asking "company doctors" for help more speedily. According to the Winter's report, the EU should consider imposing similar sanctions for misconducts in all member states, and also for disclosing false or misleading information in financial statements (Rec.III.14, p.69). 


\section{References}

[1] CAMPBELL, C. B. (1991): Underdown: Corporate Insolvency in Practice. London, Chapman \& Hall, 1991.

[2] DAMODARAN, A. (1997): Corporate Finance. New York, John Wiley, 1997.

[3] EMERY, D. R. - FINNERTY, J. D. (1991): Principles of Finance with Corporate Application. St. Paul, West Publishing Company, 1991.

[4] GREEN, S. (1992): Managerial Motivation and Strategy in Management Buy-Outs. A Cultural Analysis. Journal of Management Studies, 1992, Vol. 29, No. 4, pp. 513-535.

[5] HART, O. (1995): Corporate Governance: Some Theory and Implications. The Economic Journal, 1995, Vol. 105, No. 430, pp. 678-689.

[6] JENSEN, M. C. - MECKLING, W. H. (1976): Theory of the Firm: Managerial Behavior, Agency Costs and Ownership Structure. Journal of Financial Economics, 1976, Vol. 3, No. 4, pp. 305-360.

[7] JENSEN, M. C. (1986): The Agency Cost of Free Cash Flow: Corporate Finance and Takeovers. American Economic Review, 1986, Vol. 76, No. 2, pp. 323-329.

[8] JENSEN, M. C. (1986): The Takeover Controversy: Analysis and Evidence. The Midland Corporate Finance Journal, 1986, Vol. 4, No. 2, pp. 465-491:

[9] JERZEMOWSKA, M. (1999): Kształtowanie struktury kapitału w spółkach akcyjnych. Warszawa, Wydawnictwo Naukowe PWN, 1999.

[10] KIM, K. A. - NOFSINGER, J. R. (2004): Corporate Governance. Englewood Cliffs, Prentice Hall, 2004.

[11] MASULIS, R. (1988): Debt / Equity Choice. Cambridge, Ballinger, 1988.

[12] MOYER, R. C. - McGUIGAN, J. R. - KRETLOW, W. J. (1992): Contemporary Financial management. St. Paul, West Publishing Company, 1992.

[13] MURPHY, K .J. (1985): Corporate Performance and managerial Remuneration: An Empirical Analysis. Journal of Accounting and Economics, 1985, Vol. 30, No. pp. 245-278.

[14] PETERSON, P. P. (1994): Financial Management and Analysis. New York, McGraw-Hill, 1994.

[15] PROWSE, S. D. (1990): Institutional Investment Patterns and Corporate Financial Behavior in United States and Japan. Journal of Financial Economics, 1990, Vol. 27, No. 1, pp. 43-66.

[16] ROSS, S. A. - WESTERFIELD, R. W. - JAFFE, J. (2005): Corporate Finance. New York, McGraw-Hill, 2005.

[17] SAMUELS, J. M. - WILKES, F. M. - BRAYSHAW, R. E. (1995): Management of Company Finance. London, Chapman \& Hall, 1995.

[18] SHAPIRO, A. (1999): Modern Corporate Finance. Englewood Cliffs, Prentice Hall, 1999.

[19] WILliAMSON, O. E. (1988): Corporate Finance and Corporate Governance. The Journal of Finance, 1988, Vol. 43, No. 3, pp. 567-591. 


\title{
Hlavní problémy vztahu zastoupení a jejich následky
}

\author{
Magdalena Jerzemowska
}

\begin{abstract}
Abstrakt
Hlavním cílem této práce je představit nejdůležitější konflikty zájmů mezi ,,agenty a principály“ spolu s mechanismem minimalizování těchto konfliktů. Redukce volných peněžních toků užitím dluhového financování s využitím ochranných dluhových ujednáních, je důležitým nástrojem redukce nákladů zastoupení. V práci je ukázáno jakým způsobem sníží přírůstek vlastního kapitálu koncentraci vlastnictví manažerů, kteří jsou tak více motivováni k plýtvání zdroji, zatímco užití dluhového financování snižuje volné peněžní toky a současně též snižuje možnost manažerů plýtvat zdroji jimi ř́zené společnosti. V této práci jsou též prezentovány nejrůznější typy ochranných dluhových ujednání. Akcionáři musí platit vyšší úrokové platby jakožto cenu za pojištění proti sobeckým zájmům manažerů. Proto často dochází $\mathrm{k}$ tomu, že se akcionáři dohodnou s majiteli dluhopisů v dobré víré, že zaplatí nižší úrok. Tyto dohody jsou inkorporovány v dokumentaci mezi akcionáři a držiteli dluhopisů. Zmíněná ochranná ujednání by měla redukovat náklady bankrotu a nakonec tak zvýšit hodnotu firmy.
\end{abstract}

Klíčová slova: konflikt; teorie zastoupení; smlouvy.

\section{The Main Agency Problems and Their Consequences}

\begin{abstract}
The main aim of the paper is to present the most important conflicts of interest between "agents and principals" as well as the mechanisms for limiting these conflicts. The reduction of free cash flow through the use of debt, and the use of protective bond covenants, are important means of reducing agency costs. It is pointed out that new equity dilutes the holdings of managers with equity interests, increasing their motive to waste resources, while debt reduces free cash flow, and the opportunity for managers to waste resources. Various types of protective covenants are presented in the paper. Because shareholders must pay higher interest rates as insurance against their own selfish strategies they frequently make agreements with bondholders in the hope of paying lower interest rates. These agreements are incorporated as part of the loan document between shareholders and bondholders. These protective covenants should reduce the costs of bankruptcy and ultimately increase the value of the firm.
\end{abstract}

Key words: conflict; agency theory; covenants.

JEL classification: G30 